\title{
Incontinentia Pigmenti: A Case Report
}

\author{
Shrestha $\mathbf{R}^{1}$, Kayastha $\mathrm{BMM}^{2}$, Reema $\mathrm{A}^{3}$ \\ ${ }^{1}$ Dr. Rushma Shrestha, MBBS, MD, Clinical Tutor, \\ ${ }^{2}$ Dr. Bhaskar MM Kayastha, MBBS, MD, Professor and \\ Head, ${ }^{3} \mathrm{Dr}$. Aishath Reema, MBBS, MD Resident. All \\ from the Department of Dermatology, National academy \\ of Medical Sciences (NAMS), Bir Hospital, Kathmandu, \\ Nepal.
}

\section{Introduction}

ncontinentia pigmenti, also known as BlochSulzberger disease, is a rare X-linked dominant condition characterized by abnormalities in skin, eyes, teeth, bones and the central nervous system. It appears most commonly in girls. There are four stages of the disease: vesicular; verrucous; hyperpigmented and hypopigmented. Here we present a case of Incontinentia Pigmenti in which all the stages of the disease were present, as, it is not a common presentation in our OPD.

\section{The Case}

A seven year old female child from Jumla District (a part of Karnali Zone, situated in the mid-western part of Nepal), studying in grade one presented with multiple vesicles, bullae, hyperkeratotic papules and hypopigmented patches all over the body of five years duration. According to the patient's father, the child was a full term normal home delivery. At the age of two year they noticed a warty plaque at the medial aspect of left ankle joint which was preceded by vesicles. Gradually she started developing similar lesions on different parts of the body which would start as vesicles and bullae, then become hyperkeratotic and some lesions became hyperpigmented or hypopigmented. The lesions are still increasing in size.

The father of the patient was married twice. He has four children from the first wife; one son and three daughters. All are healthy. From the second wife, he had five children: two sons and three daughters but the 1st child, which was a male, died 2 to 4 months after birth.

\begin{abstract}
Incontinentia pigmenti is a rare $\mathrm{X}$-linked dominant condition characterized by abnormalities in skin, eyes, teeth, bones and the central nervous system. A seven year old female child presented to the Dermatology Out Patient Department (OPD) of Bir Hospital with vesicles, bullae, verrucous papules and plaques and hypopigmented streaks on the trunk and extremities of six years duration. Based on the clinical findings she was diagnosed as a case of Incontinentia pigmenti.
\end{abstract}

Cause of death was not known. Our patient is the third from his second wife. All the other siblings are healthy. There is no parental consanguinity. There is no history of similar skin lesions in her family or first degree relatives.

On physical examination, the patient is of average built weighing $25 \mathrm{kgs}$. Her systemic examination was normal. On cutaneous examination, there were multiple vesicles, bullae, erosions on different parts of the body as well as verrucous hyperkeratotic papules and plaques, hyper- and hypopigmented streaks distributed in bizarre pattern following the lines of Blaschko. The lesions were more on the trunk and extremities. Head and neck, palms and soles were spared [Figure 1 and 2]. However there were no extracutaneous manifestations like the teeth, CNS, bone and eye changes.

The haematological parameters were within normal limits. Histopathological examination showed keratinized stratified squamous epithelium showing verrucous acanthosis, compact hyperkeratosis, spongiosis within the spinous layer and foci of intraepidermal keratinization. Reduced melanin along with vacuolations was noted in the basal cells in some foci. Eosinophils were found in the upper dermis and few within the epidermis. The dermis was infiltrated by mixed inflammatory cells. Few melanin pigments were also noted within the dermis.

\author{
Address for correspondence \\ Dr. Rushma Shrestha \\ Clinical Tutor \\ Department of Dermatology, \\ National Academy of Medical Sciences, Bir Hospital \\ Kathmandu, Nepal \\ E-mail: rushma_100@yahoo.com
}

\section{How to cite this article?}

Shrestha R, Kayastha BMM, Reema A. Incontinentia Pigmenti: A Case Report. J Nepal Paediatr Soc 2013;33(1):57-60. 


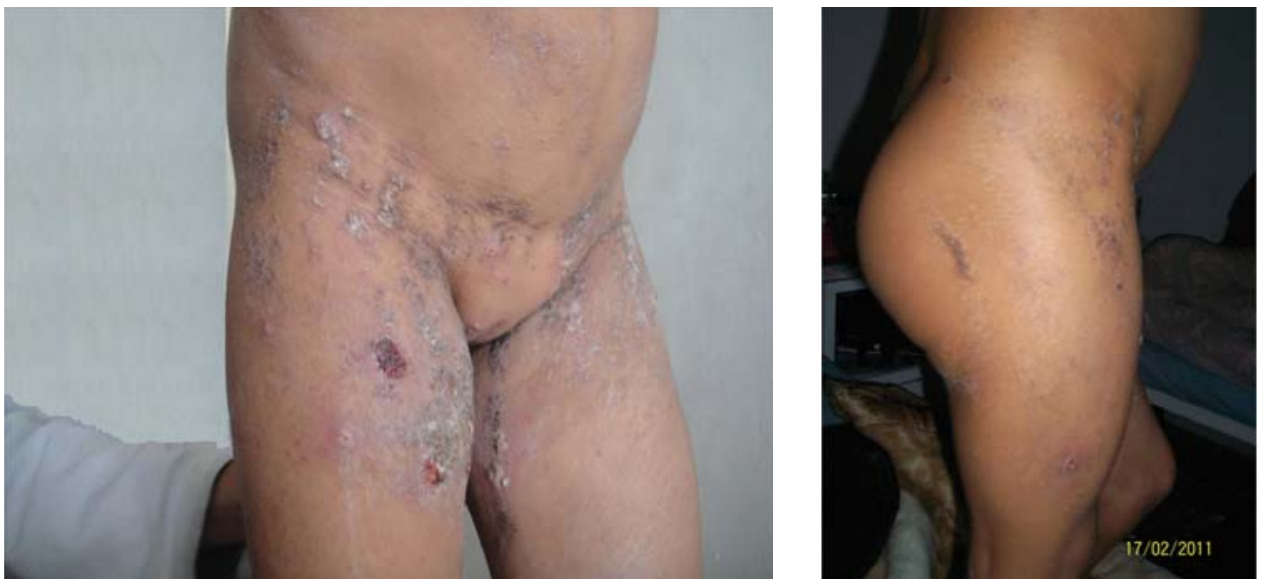

Fig 1and 2: Showing linear verrucous lesions with vesicles, bullae and erosions
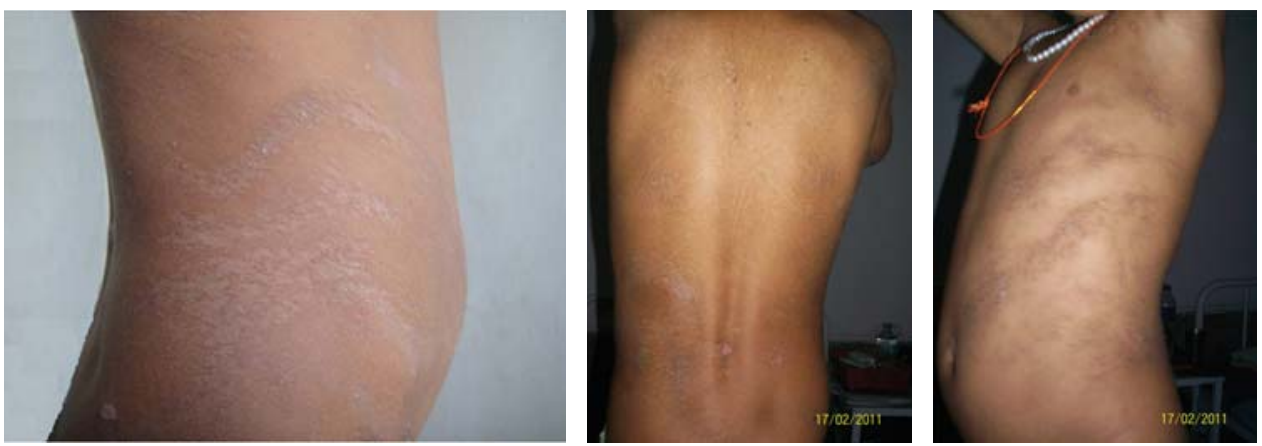

Fig 3, 4 and 5: Linear hyper-and hypopigmented streaks

On the basis of clinical and histopathological findings the patient was diagnosed as incontinentia pigmenti.

The secondary infections were treated with oral cefadroxil $250 \mathrm{mg} \times$ bid $\times 7$ days and topical fusidic acid.

\section{Discussion}

Incontinentia pigmenti also known as BlochSulzberger syndrome or Bloch-Siemens syndrome is a rare and complex hereditary syndrome in which vesicular, verrucous and pigmented cutaneous lesions are associated with developmental defects of the teeth, eye, bone and $\mathrm{CNS}^{1}$. This syndrome mainly affects females ${ }^{2,3}$ and is lethal in males ${ }^{4}$.

The genetic defect lies on the $X$ chromosome, localized to $\mathrm{Xq28}$. It is related to the NF kappa B essential modulator (NEMO) gene ${ }^{5,6}$. Rabia HS et.al has reported 25 adults with IP and nuclear factor-kB essential modulator gene rearrangement or mutations ${ }^{7}$.

Four distinct clinical stages are recognized ${ }^{8}$ :

Stage 1: inflammatory macules, papules, vesicles and pustules

Stage 2: hyperkeratotic and verrucous lesions
Stage 3: grey-brown pigmentation

Stage 4: atrophic, hypopigmented and depigmented bands or streaks that are hairless and anhidrotic and fail to tan on sun exposure.

Stage 1 usually begins between 0-2 weeks of age and persists for 2 months. Stage 2 usually starts between the second and sixth week of life. The pigmentary stages usually starts between the $12^{\text {th }}$ and $26^{\text {th }}$ week of life, which progresses upto the $2^{\text {nd }}$ year and fades by the $2^{\text {nd }}$ and $3^{\text {rd }}$ decade of life ${ }^{9}$.

Hair changes may be seen at the vertex in the form of cicatricial alopecia.

Nail changes may also be present in cases with incontinentia pigmenti ${ }^{10}$. Aggarwal K, Jain VK, Dayal S has reported a case of incontinentia pigmenti, with nail dystrophy and onycholysis ${ }^{11}$.

The extracutaneous manifestations are seen in more than half of the patients with incontinentia pigmenti:

1. Dental defects can be seen in the form of partial anodontia, pegged teeth and missing teeth, particularly the upper lateral incisors and the premolars $^{12,13}$. 
2. In ophthalmologic findings, there may be blindness, strabismus, cataracts, retinal detachment, optic atrophy and microphthalmia ${ }^{14,15,16}$. Minić $S$ et.al has done meta-analysis of 1931 incontinentia pigmenti patients with ocular abnormalities ${ }^{17}$.

3. The central nervous system defect includes seizures, mental retardation, spastic paralysis, microencephaly and slow motor development ${ }^{18,19,20}$.

4. Sketal abnormalities can present with skull deformities, dwarfism, spina bifida, club foot, extra ribs, cleft palate and cleft lips.

Leukocytosis and eosinophilia ${ }^{21}$ are common findings. Histopathological features differs with the clinical stage of the disease. In the first stage, there are intraepidermal vesicles with eosinophilic spongiosis. In the second stage, there is acanthosis, hyperkeratosis and papillomatosis with persistent presence of necrotic keratinocytes and the final stages of pigmentation is due to melanin in melanophages in the upper dermis.

\section{Conclusion}

Incontinentia pigmenti should be differentiated from linear and whorled nevoid hypermelanosis, epidermolysis bullosa and childhood bullous pemphigoid, NaegeliFranceschtti-Jadassohn syndrome and incontinentia pigmenti achromians ${ }^{22}$. Treatment is not necessary other than the control of secondary infection as the lesions spontaneously subside in adulthood.

\section{References}

1. Berlin AL, Paller AS, Chan LS. Incontinentia pigmenti: a review and update on the molecular basis of pathophysiology. Am Acad Dermatol 2002; 47:169-87.

2. Pereira MA, Mesquita LA, Budel AR, Cabral CS, Feltrim Ade S. X-linked incontinentia pigmenti or Bloch-Sulzberger syndrome: a case report. An Bras Dermatol 2010; 85(3):372-5.

3. Nazzaro V, Brusasco A, Gelmetti C, Ermacora E and Caputo R. Hypochromic Reticulated Streaks in Incontinentia pigmenti: An immunohistochemical and Ultrastructural study. Pediatr Dermatol 1990;7(3):174-78.

4. Wiklund DA, William L, Weston MD. Incontinentia pigmenti : A four generation study. Arch Dermatol 1980;116:701-3.

5. Motamedi MH, Lotfi A, Azizi T, Moshref M, Farhadi S. Incontinentia pigmenti. Indian J Pathol Microbiol 2010;53(2):302-304.

6. Smahi A, Courtois G, Vabres P, Yamaoka S, Heuertz $S$ and Munnich A, et al. Genomic rearrangement in NEMO impairs NF-KB activation and is a cause of incontinentia pigmenti: the international incontinentia pigmenti (IP) consortium. Nature 40;2000;466-472.

7. Rabia SH, Rimella A, Smahi A, Fraitag S, Teillac DH, Bonnefont JP, et.al. Clinical and histologic features of incontinentia pigmenti in adults with nuclear factor-kB essential modulator gene mutations. J Am Acad Dermatol 2011; 64(3):508-515.

8. Anstey AV. Disorders of skin colour. In:Burns T, Breathnach S, Cox N, Griffiths C, eds. Rook's Textbook of Dermatology: Volume 3, Eighth edition, Wiley-blackwell publishing 2010.p.58.15.

9. Dutta AK, Dutta PK, Dhar S. In:valia RG, Valia AR, eds. IADVL Textbook of Dermatology: Volume 1, $2^{\text {nd }}$ ed, Mumbai:Bhalani publishing house; 2003.p.634.

10. Chun SR, Rashid RM. Delayed onychodystrophy of incontinentia pigmenti : an evidence-based review of epidemiology, diagnosis and management. J Drugs Dermatol 2010;9(4):350-4.

11. Aggarwal K, Jain VK, Dayal S. Incontinentia Pigmenti with nail dystrophy. Indian J Dermatol Venereol Leprol 2003;69(7):3-4.

12. Wu HP, Wang $\mathrm{YL}$, Chang HH. Dental anomalies in two patients with incontinentia pigmenti. J Formos Med Assoc 2005;104(6):427-30.

13. Minic S, Novotny GEK, Trpinac D, Obradovic M. Clinical features of incontinentia pigmenti with emphasis on oral and dental abnormalities. Clin Oral Invest 2006;10:343-347.

14. Minic S, Novotny GE, Stefanovic I, Obradovic M, Trpinac D. Ophthalmological findings in series of incontinentia pigmenti patients from Serbia. Srp Arh Celok Lek 2010;138(3-4):150-3.

15. Wald KJ, Mehta MC, Katsumi O, Sabates NR, Hirose T. Retinal Detachments in Incontinentia Pigmenti. Arch Ophthalmol 1993;111(5):614-617.

16. Mayer EJ, Shuttleworth GN, Greenhalgh KL. Novel corneal features in two males with incontinentia pigmenti. Br J Ophthalmol 2003;87(5):554-6.

17. Minic S, Obradović M, Kovacević I, Trpinac D. Ocular anomalies in incontinentia pigmenti: literature review and meta-analysis. Srp Arh Celok Lek 2010;138(7-8):408-13.

18. Fiorillo L, Sinclair DB, O'Byrne ML. Bilateral cerebrovascular accidents in incontinentia pigmenti. Pediatr Neurol 2003;29(1):66-8.

19. Shah SN, Gibbs S, Upton CJ. Incontinentia pigmenti associated with cerebral palsy and cerebral leukomalacia: a case report and literature review. Pediatr Dermatol 2003;20(6):491-4. 
20. Kaczala GW, Messer MA, Poskitt KJ, Prendiville JS, Gardiner J, Senger C. Therapy resistant neonatal seizures, linear vesicular rash and unusually early neuroradiological changes: incontinentia pigmenti. Eur J Pediatr 2008;167:979-83.
21. Agarwal P. Incontinentia pigmenti. Indian J Dermatol Venereol Leprol 1997;63:368-9.

22. Thapa R. Pigmentary mosaicism: An update. Indian J Dermatol 2008;53:96-7. 